\title{
Assessment of Bitterness Reduction on Green Olive by Using Plant Growth Regulators
}

\author{
Ozdemir $\mathrm{Y}^{1 *}$, Kayahan $\mathrm{S}^{1}$ and Keskinel $0^{2}$ \\ ${ }^{1}$ Ataturk Central Horticultural Research Institute, Department of Food Technologies, \\ Yalova, Turkey \\ ${ }^{2}$ Ankara University, Department of Food Engineering, Ankara, Turkey
}

Research Article

Volume 3 Issue 6

Received Date: August 06, 2018

Published Date: August 18, 2018

*Corresponding author: Yasin Ozdemir, Ataturk Central Horticultural Research Institute, Department of Food Technologies, Yalova, Turkey, Tel: 2268142520; Email: yasin.ozdemir@tarim.gov.tr

\section{Abstract}

This is the first study which is aimed to develop a new table olive production method with reduction of olive bitterness by keeping olives in plant growth regulator contained water. The hypothesis of this study was that plant growth regulator at low levels will accelerate the ripening of olives during these process bitterness of olives will reduce. Oleuropein was responsible from bitter taste of olives. According to previous studies during olive ripening oleuropein content of olives were decreased and it will cause reduction on bitterness of olives. Indole-3-acetic acid, 2,4-dichlorophenoxyacetic acid, gibberellic acid, ethephon and Signum (containing $267 \mathrm{~g} / \mathrm{kg}$ boscalid and $67 \mathrm{~g} / \mathrm{kg}$ pyraclostrobin) used individually in this study. Bitterness of olives was analyzed by oleuropein absorbance value and sensorial taste analysis with 2 day intervals until 8 days. There was no negative effect on color and tissue hardness value of olives but bitterness of olives did not reduce to acceptable level at the end of this experiment. Future studies should be focused on using of plant growth regulators especially chemical substances which had ripeness accelerator properties on olives to reduce the bitterness of olives.

Keywords: Postharvest; Ethephon; Ripening; Oleuropein

\section{Introduction}

Phytohormones regulate numerous aspects of plant growth and postharvest fruit quality [1]. Recent concepts suggest that ripening of some fruit during postharvest storages are not only deteriorative processes which was need to slow down but also useful processes in which some growth regulators play important roles such as ripening acceleration of palm, banana and olive in some extend [1,2]. Ethylene is still considered a major influence on postharvest metabolism, the other plant hormones, the auxins, gibberellins, cytokinins, and abscisic acid, are also thought to significantly influence the aging process [3-5].

Applying different types of plant regulators such as auxin, gibberellin and its combination without giving unfavorable effects to the quality of banana was studied [1,6]. 2,4-Dichlorophenoxyacetic acid is an auxin-like 


\section{Open Access Journal of Agricultural Research}

plant growth regulator. Since the 1940s, 2,4Dichlorophenoxyacetic acid and its derivatives have been widely used during citrus postharvest handling to maintain fruit quality [7]. Green-mature banana fruit were treated with deionized water, abscisic acid, indole3-acetic acid and abscisic acid + indole-3-acetic acid, respectively, to investigate the role of them in fruit ripening. Results showed that abscisic acid accelerated fruit ripening, but indole-3-acetic acid delayed the process. However, treatment of abscisic acid + indole-3acetic acid showed little difference in fruit color and firmness [1]. Palm fruit bunches were exposed to 0,250 , 500 or 1000 ppm ethylene for 24 hours. Each fruit bunch was evaluated in three separate sections: the bottom, the middle, and the top. The exogenous ethylene treatments significantly hastened palm fruit ripening, quantified by an increase in the fruit peel coloring that turns from black to reddish orange. Exogenous ethylene fumigation accelerated the ripening of oil palm fruit, increased oil yield, and decreased the free fatty acid levels [2]. Exogenous treatment with indole-3-acetic acid on the ripening of olives reported as a significant increase in the accumulation of fat and the amounts of extracted oils and a significant improvement in the extractability of phenolic content diffusible in these oils at maturity [8].

The aim of this study was to develop a new olive debittering method for table olive processing industry. Fort this aim green olives were kept in water which contain Indole-3-acetic acid, 2,4-dichlorophenoxyacetic acid, gibberellic acid, ethephon and Signum (containing $267 \mathrm{~g} / \mathrm{kg}$ boscalid and $67 \mathrm{~g} / \mathrm{kg}$ pyraclostrobin) after that some physical, chemical and sensory analyzed were applied to the olives.

\section{Materials and Methods}

\section{Material}

Maturity index of Gemlik variety olive fruits were followed according and olives were hand-picked at 1 maturation index when olives skin was green/yellow color in harvest season of 2014/2015 from genotype observation orchard of Ataturk Central Horticultural Research Institute (Yalova/Turkey) [9,10]. Olives were sorted according to size and 3.7-4 $\mathrm{g}$ of olives was used for this trial.

\section{Debittering Experiment}

Olives were washed without delay and diseased and damaged olives were removed. $1 \mathrm{~kg}$ olives were put $3 \mathrm{~L}$ of water which contain plant growth regulators which are;
0.2 ppm indole-3-acetic acid, 10-3 M2,4dichlorophenoxyacetic acid, 50 ppm gibberellic acid, 4.8 ppm ethephon and $0.2 \mathrm{ppm}$ SIGNUM (containing $267 \mathrm{~g} / \mathrm{kg}$ boscalid and $67 \mathrm{~g} / \mathrm{kg}$ pyraclostrobin) individually at $20 \pm 2^{\circ} \mathrm{C}$. Olives were kept in water without growth regulators for control. During debittering experiment, olives were analyzed with sensorial odor, appearance and bitterness by panelists at 2 day intervals. The limit for odor and appearance tolerance $<5.5$ and for bitterness was set at $7.5<$ because slight bitter taste in table olive is desirable by consumers [11,12]. At the end of 8 days experiment was stopped due to unfavorable odor $(<5.5$ point from sensory taste) of olives. All olive samples were analyzed immediately after debittering experiment.

\section{Analysis}

$\mathrm{pH}$ and titratable acidity content of olives were determined according to official method TS 774 [13]. Color values of olive skin were measured with a color meter (Konica Minolta, Japan) at $23 \pm 1^{\circ} \mathrm{C}$. Water content of olive samples was determined in a conventional oven at $75 \pm 2^{\circ} \mathrm{C}$ [14]. Texture hardness of olive was measured with fruit harness tester (W.O.W FRH-5, Japan).Color and texture hardness analyses were run in 15 replicates. Absorbance value of oleuropein was determined by spectrophotometric method at $345 \mathrm{~nm}$ according to Mastorakis, et al. [15].

The sensory profiles of olives were assessed with sensory profile sheet used by the trained judges according to Aponte M, et al. [16]. Sensory characteristics were evaluated with 9 point scale (9: like extremely, 8: like very much, 7: like moderately, 6: like slightly, 5: neither like nor dislike, 4: dislike slightly, 3: dislike moderately, 2: dislike very much and 1: dislike extremely) by panelists. Sample preparation, serving and tasting procedures were organized according to Galán-Soldevilla and Pérez-Cacho [17]. The appearance and color attributes were assessed by the panelists on the complete sample before tasting. Odor, taste and bitterness were evaluated respectively.

\section{Statistical analysis}

Randomized experimental design was used and analysis of variance was applied with the Duncan multiple comparison test of the means $(\mathrm{p}<0.01)$ to determine the presence of significant differences among the samples. Statistical analysis was performed by using the JMP v. 5.0 statistical package programs (SAS Institute, Cary, N.C.,U.S.A.). Different letters indicate significant difference in same colon of tables. 


\section{Open Access Journal of Agricultural Research}

\section{Results and Discussion}

Color and hardness are the important characters which highly affect the preference of consumer for table olive marketing [18]. So that these values should be controlled for developing new table olive processing methods. Color value and hardness of olive samples were given in Table 1.L value, a value, $\mathrm{b}$ value and hardness of green table olives were reported as 49.96-69.56, 1.35-17.91, 19.57-45.47 and 434.1-895.7 g. respectively [19]. In this study b value and hardness of olives were determined as similar but $\mathrm{L}$ and a color values were determined lower than Kiritsakis [19].

\begin{tabular}{|c|c|c|c|c|}
\hline \multirow{2}{*}{ Sample } & \multicolumn{3}{|c|}{ Color values } & \multirow{2}{*}{ Hardness (g) } \\
\cline { 2 - 5 } & $\mathbf{L}$ & $\mathbf{a}$ & $\mathbf{b}$ & \\
\hline 2,4 dichlorophenoxyacetic acid & $34.76 \mathrm{c}$ & 0.77 & $12.30 \mathrm{c}$ & $456 \mathrm{c}$ \\
\hline Gibberellic acid & $36.84 \mathrm{~b}$ & 0.82 & $17.55 \mathrm{~b}$ & $429 \mathrm{c}$ \\
\hline Indole-3-acetic acid & $33.72 \mathrm{c}$ & 0.8 & $16.38 \mathrm{~b}$ & $525 \mathrm{~b}$ \\
\hline Signum & $36.19 \mathrm{~b}$ & 0.94 & $12.96 \mathrm{c}$ & $379 \mathrm{~d}$ \\
\hline Ethephon & $34.58 \mathrm{c}$ & 0.73 & $15.77 \mathrm{~b}$ & $516 \mathrm{~b}$ \\
\hline Control & $37.62 \mathrm{~b}$ & 0.7 & $16.41 \mathrm{~b}$ & $520 \mathrm{~b}$ \\
\hline Raw olive & $39.26 \mathrm{a}$ & 0.76 & $26.25 \mathrm{a}$ & $627 \mathrm{a}$ \\
\hline
\end{tabular}

Table 1. Color value and hardness of olives.

Water content, oleuropein absorbance value, $\mathrm{pH}$ and titratable acidity content of olive samples were given in Table 2. $\mathrm{pH}$ value, titratable acidity and water content of green olives were reported as between 2.80-3.97, $0.59-1.40$ and 63.1-73.2 \% [18,19]. Oleuropein absorbance value of raw and processed Gemlik olives was reported as 0.57 and between $0.06-0.16$ by Kumral et al whose results were lower than that was found in this study [20]. There were statistically significant differences for reduction in oleuropein absorbans value. Higher reduction was detected for ethephon treated olive samples.

\begin{tabular}{|c|c|c|c|c|}
\hline Sample & Water (\%) & $\begin{array}{c}\text { Oleuropein absorbance } \\
\text { value (K.45) }\end{array}$ & pH & $\begin{array}{c}\text { Titratable acidity (\% } \\
\text { oleic acid) }\end{array}$ \\
\hline 2,4 dichlorophenoxyacetic acid & $67.71 \mathrm{a}$ & $0.78 \mathrm{~b}$ & 5.03 & 0.14 \\
\hline Gibberellic acid & $67.33 \mathrm{a}$ & $0.90 \mathrm{a}$ & 5.26 & 0.14 \\
\hline Indole-3-acetic acid & $66.74 \mathrm{ab}$ & $0.76 \mathrm{~b}$ & 5.17 & 0.16 \\
\hline Signum & $67.48 \mathrm{~b}$ & $0.79 \mathrm{~b}$ & 5.21 & 0.17 \\
\hline Ethephon & $67.55 \mathrm{~b}$ & $0.63 \mathrm{c}$ & 5.02 & 0.14 \\
\hline Control & $68.36 \mathrm{a}$ & $0.84 \mathrm{ab}$ & 5.14 & 0.16 \\
\hline Raw olive & $66.92 \mathrm{~b}$ & $0.92 \mathrm{a}$ & 5.22 & 0.17 \\
\hline
\end{tabular}

Table 2: Water content, oleuropein absorbance value, $\mathrm{pH}$ and titratable acidity content of olives.

Sensory characters; appearance, color, odor, taste and bitterness scores were given in Table 3. Appearance, odor and bitterness taste of green olives were reported between $8.99-9.05,7.87-8.06$ and $3.18-3.21$ by using $1-11$ point sensory score scale [21]. Sensory determined color acclaim value was reported between 5.6-9.0 (0-10 point score) for green olives by Ozdemir and Kurultay [22].

\begin{tabular}{|c|c|c|c|c|c|}
\hline \multirow{2}{*}{ Sample } & \multicolumn{5}{|c|}{ Sensory characters } \\
\cline { 2 - 5 } & Appearance & Color & Odor & Taste & Bitterness \\
\hline 2,4 dichlorophenoxyacetic acid & $7.7 \mathrm{a}$ & $7.0 \mathrm{~b}$ & $6.2 \mathrm{a}$ & 2.1 & $1.8 \mathrm{ab}$ \\
\hline Gibberellic acid & $6.7 \mathrm{~b}$ & $7.5 \mathrm{~b}$ & $4.8 \mathrm{ab}$ & 2 & $1.0 \mathrm{c}$ \\
\hline Indole-3-acetic acid & $7.4 \mathrm{ab}$ & $7.2 \mathrm{~b}$ & $6.0 \mathrm{a}$ & 1.7 & $2.0 \mathrm{a}$ \\
\hline Signum & $5.0 \mathrm{c}$ & $5.2 \mathrm{a}$ & $4.4 \mathrm{c}$ & 1.5 & $1.4 \mathrm{~b}$ \\
\hline Ethephon & $7.0 \mathrm{~b}$ & $7.3 \mathrm{~b}$ & $5.0 \mathrm{~b}$ & 2 & $2.3 \mathrm{a}$ \\
\hline Control & $6.8 \mathrm{~b}$ & $7.8 \mathrm{~b}$ & $6.3 \mathrm{a}$ & 2 & $1.2 \mathrm{c}$ \\
\hline
\end{tabular}

Table 3: Sensory evaluation scores of olives (1-9). 


\section{Open Access Journal of Agricultural Research}

In this study appearance and color values were determined at higher than acceptable level (5.5) except Signum treated sample. Odor was determined as unacceptable at the end of 8 days for gibberellic acid, Signum and ethephon treated olives. Odor and taste scores were lower than López-López et al [21]. Bitterness reduction of olives was not succeeded to reduce favorable level in this experiment so that scores of taste and bitterness were lower than acceptable levels.

\section{Conclusion}

In this study, debittering of olives relies upon indigenous enzymes from raw material whose enzymes were expected to accelerated by added plant growth regulators. This practice may lead to fluctuations in the final oleuropein absorbance value and sensory bitterness scores of samples at the end of 8 days. In this study reduction of bitterness was not appropriate to suggest to producer but statistical significant reduction of oleuropein absorbance value and sensory bitterness results indicated that plant growth regulators especially enhancers has potential for develop new olive debittering methods for table olive industry. Future studies should be focus on different types, doses and conditions of ripening enhancer component to develop new olive debittering method.

\section{Acknowledgment}

Authors thanks to Ataturk Central Horticultural Research Institute (Yalova/Turkey) which supported this study.

\section{References}

1. Lu W, Mao L, Chen J, Han X, Ren X, et al. (2018) Interaction of abscisic acid and auxin on gene expression involved in banana ripening. Acta Physiologiae Plantarum 40(3): 46.

2. Nualwijit N, Lerslerwong L (2014) Post harvest ripening of oil palm fruit is accelerated by application of exogenous ethylene. Songklanakarin J Sci Technol 36(3): 255-259.

3. Hu B, Li J, Wang D, Wang H, Qin Y, et al. (2018) Transcriptome profiling of Litchi chinensis pericarp in response to exogenous cytokinins and abscisic acid. Plant Growth Regulation 84(3): 437-450.

4. Coggins CW, Lovatt CJ (2014) 14 Plant Growth Regulators. Citrus Production Manual 3539: 215.
5. Pech JC, Bouzayen M, Latché A (2008) Climacteric fruit ripening: ethylene-dependent and independent regulation of ripening pathways in melon fruit. Plant Science 175(1-2): 114-120.

6. Sembok WZW, Hamzah Y, Loqman NA (2016) Effect of Plant Growth Regulators on Postharvest Quality Of Banana. J Trop Plant Physiol 8: 52-60.

7. Ma Q Ding Y, Chang J, Sun X, Zhang L, et al. (2013) Comprehensive insights on how 2,4dichlorophenoxyacetic acid retards senescence in post-harvest citrus fruits using transcriptomic and proteomic approaches. Journal of experimental botany 65(1): 61-74.

8. Moustakime Y, Hazzoumi Z, Fatemi ZEA, Joutei KA (2017) Effect of exogenous application of indole-3acetic acid (IAA) on cell maturity of Olea europaea L. and extractability of phenolic compounds in virgin olive oil. Journal of Applied Pharmaceutical Science 7(2): 199-206.

9. Berenguer MJ, Vossen PM, Grattan SR, Connell JH, Polito VS (2006) Tree irrigation levels for optimum chemical and sensory properties of olive oil. HortScience 41(2): 427-432.

10. Kiritsakis AK (1998) Composition of Olive Oil, Olive Oil From The Tree To The Table. Food \& Nutrion Press Inc 348, USA $2^{\text {nd }}($ Edn).

11. Lanza B (2012) Nutritional and sensory quality of table olives. Olive Germplasm pp: 343-372.

12. Panagou EZ, Tassou CC, Katsaboxakis KZ (2002) Microbiological, physicochemical and organoleptic changes in dry salted olives of Thassos variety stored under different modified atmospheres at 4 and $20^{\circ} \mathrm{C}$. International Journal of Food Science and Technology 37(6): 635- 641.

13. TS 774 (1992) Turkish Standards Institute, Turkish Table Olive Standard. Ankara, Turkey.

14. Zeleke K, Mailer R, Eberbach P, Wünsche J (2012) Oil content and fruit quality of nine olive (Olea europaea L.) varieties affected by irrigation and harvest times. New Zealand journal of crop and horticultural science 40(4): 241-252.

15. Mastorakis M, Sotiroudis TG, Xenakis A, MiniadisMeimaroglou S (2004) Spectrophotometric analysis 


\section{Open Access Journal of Agricultural Research}

of enzymic and non-enzymic oxidation of oleuropein. Chemistry and Physics of Lipids 130(1): 58.

16. Aponte M, Ventorino V, Blaiotta G, Volpe G, Farina V, et al. (2010) Study of green Sicilian table olive fermentations through microbiological, chemical and sensory analyses. Food Microbiology 27(1): 162-170.

17. Galán-Soldevilla H, Pérez-Cacho PR (2010) Sensory characterization of Alore-a olives Universidad de Córdoba (Córdoba-Spain). Private report to the Manzanilla-Alore-a industrial sector.

18. Cano-Lamadrid M, Girón IF, Pleite R, Burló F, Corell M, et al. (2015) Quality attributes of table olives as affected by regulated deficit irrigation. LWT-Food Science and Technology 62(1): 19-26.

19. Yilmaz E, Aydeniz B (2012) Sensory evaluation and consumer perception of some commercial green table olives. British Food Journal 114(8): 1085-1094.
20. Kumral A, Basoglu F, Sahin I (2009) Effect of the use of different lactic starters on the microbiological and physicochemical characteristics of naturally black table olives of Gemlik cultivar. Journal of food processing and preservation 33(5): 651-664.

21. López-López A, Moreno-Baquero JM, RodríguezGómez F, García-García P, Garrido-Fernández A (2018) Sensory Assessment by Consumers of Traditional and Potentially Probiotic Green SpanishStyle Table Olives. Frontiers in nutrition 5: 53.

22. Ozdemır Y, Kurultay S (2016) Physical and chemical characteristics of crossed olives and their convenience to green table olive fermentation by using Lactobacillus plantarum as a starter culture. Scientific Bulletin Series F Biotechnologies 20: 154-161.

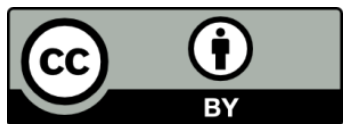

